
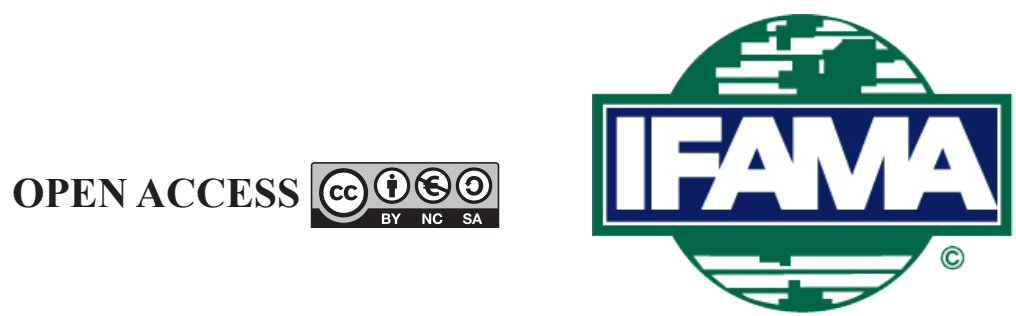

International Food and Agribusiness Management Review

Volume 23, Issue 5, 2020; DOI: 10.22434/IFAMR2019.0183

Received: 6 November 2019 / Accepted: 20 January 2020

Special issue: New and sustainable food and agribusiness management models

\title{
A social innovation perspective on business model improvement in food related industries OPINION ARTICLE
}

\author{
Xiao-Wei Wen ${ }^{\circledR a}$,b , Sang-Luo Sun ${ }^{\mathrm{c}}$ and Zhao-Hui Yang ${ }^{\mathrm{c}}$ \\ ${ }^{a}$ Professor, ${ }^{c}$ Doctoral student, College of Economics and Management, South \\ China Agricultural University, Guangzhou 510642, China P.R. \\ ${ }^{b}$ Loonguard Research Institute, Guangzhou 510000, China P.R.
}

\begin{abstract}
Food sector sustainability should not be discussed solely through an economic lens. On the contrary, social forces are critical in motivating and practicing high-quality food production and distribution in the supply chain context. This opinion addresses food sector imperatives from the social innovation perspective to preliminarily comment on social innovation's potential influences on food production, distribution, and safety. Preliminary though, the purpose and contribution of this opinion paper are both stimulating future imagination in theory and practices for utilizing social innovation for food safety and sustainability. The main opinions are the employment of resources, sustainable development of resources, generation of finances and diversifying the talent pool for social innovative initiatives that promote food safety.
\end{abstract}

Keywords: social innovation, supply chain, food safety, sustainability JEL code: $\mathrm{O} 31$

\footnotetext{
(i) Corresponding author: wenxiaowei49@gmail.com / wxwcn@scau.edu.cn
} 


\section{Introduction}

Social innovation is defined as the creative practice of solving a certain problem in an organization, leading to the wellbeing of society and its people (Cajaiba-Santana, 2014). It is considered as the way to initiate changes for providing better solutions for social problems. Innovations that are successful possess the characteristics of inclusion, fairness, well-being, and empowerment. The basic need for implementing social innovation is to have a characteristic of more equal and fairer world so that things are equally distributed all around the organization that initiates the innovation (Mulgan, 2012). The challenges that are encountered through social innovation are inequality, climate change, food productions, poverty, unemployment, racism, migration, malnutrition, integration and mass migration (Lettice and Parekh, 2010). These are global challenges that are addressed with the help of social innovation. General education about the problem is a more effective method to solve the problem. Understanding the problem and implementing the change to mitigate the issue will bring in lasting change in the environment. There is a varied range of problems, which are unattended, and almost impossible to solve. These include climate change, issues on an epidemic, widening effect on inequalities. The aim of the paper is to provide a conceptual framework on social innovation that benefits the ecology.

Companies pursue social innovation plan to generate a range of benefits, for example, companies in some industries such as food, textile, and agriculture are more and more reliant on supply chains on procuring the raw materials from the market for high quality products. On the other hand, the IT sector focuses on social innovation solutions and on building talent pool along with this the service sector instills loyalty among the employees, which helps to increase the quality of services to the market and the whole society.

Organizations that pursue social innovation for building new markets and seeking new opportunities in the market innovate typically in three major areas. And food industry fits all of these criteria. Firstly, the companies design products and services that cater to the unique needs of the low-income group, for example, in the food industry production of the existing products with essential micronutrients that address to drive out malnutrition are served in the market. The quality of the product is enhanced by adding the new micronutrient that was not present before. Moreover, malnutrition is a significant social problem that hampers society from being productive. The food industry is the only one that can solve the issue by innovating social plans to deliver the products to the poor segment (Lettice and Parekh, 2010). Secondly, food industry characterizes the situation that the products and services are required to provide strong value against the money spent on it, because of little purchasing power of the consumers along with cost-effectiveness quality of the service or product (Huarng and Hui-Kuang Yu, 2011). The purchasing power of food consumers is decreasing over the past periods of time in less developed economies, for they are unable to construct meaning of good foods with the limits of efforts contributed to raise their living standards. Hence, the food products they buy must justify the spending incurred on it. Less purchasing power happens to be one of the major problems that can be eradicated using social innovation by various organizations. Thirdly, food companies in developing economies must make the products available across large boundaries, where infrastructures are poor, and creativity is needed to enhance the distribution channels. For instance, a Denmark based health care brand, Novo Nordisk, expanded its service to distribute insulin in several other countries, where the stock of insulin was less and people were dying out of diabetes (World Economic Forum, 2018). Food-borne diseases do not allow individuals to live a healthy life; thereby, affecting the standard of living (Oke et al., 2013). Social innovation, in this regard, can help eradicate epidemics from less developed regions.

\section{Strengthening supply chains}

The social and financial outcomes can be achieved through social innovation in the food supply chain. A suitable example of this is the experience of companies like Nestle and Jollibee. Jollibee Food Corporation is considered as the largest fast-food chain in Philippines. It is reliant on steady supply of raw materials, which include cereals, vegetables and dairy products that are available at stable prices and quality (World Economic Forum, 2018). However, it is a known fact that the Philippines is vulnerable to extreme weather 
conditions such as typhoons. When vulnerable weather conditions destroy the crop yield, the intermediaries take up the opportunity to manhandle the existing yield and charge exorbitantly for those back up yields (World Economic Forum, 2018). Therefore, for mitigating these supply chain problems, Jollibee Food Corporation started sourcing products from small landholders, who faced difficulty in selling their produce in the marketplace. The company made it easier for small farmers to carry on farming because they do not have to think about selling their products at a low rate to the intermediaries in the marketplace (Oke et al., 2013). By the end of 2015, the company had extended its helping hand to almost 900 families engaged in farming (Oke et al., 2013).

The strategic benefits of social innovation in food supply chain management are of three types. Firstly, the motivation is on accessing the supply of raw materials with high stability. This assurance of supply is needed because the intermediaries in the food industry take half the price share paid by the consumers. The benefit of having access to raw materials is extracting out those intermediaries from the supply chain system. Secondly, the small-sized cultivators can increase quality and volume of production because of the positive effect of the social innovation plan. Smallholders can abandon the crops that have become unviable until the small farmers are given the opportunity to sell their produce at market rate. For instance, there was a threat of shortage in production in cocoa that troubled the coffee producers around world. To mitigate the issue, the partnership was made with the social enterprises to help increase the cocoa productivity in countries (Wook Kim, 2006). In this case, stress is provided on making the quality of the raw materials better. Moreover, the high quality of products helps in achieving high price margins that lead to high-profit margins and strengthens the loyalty of customers.

Nespresso is a successful brand, operating in premium coffee. The company needs high-quality coffee beans along with regular supply. It is operated under the famous food brand Nestle (World Economic Forum, 2018). Over time Nestle found out that coffee farming became unattractive among the farmers, because of obvious reasons that include low productivity in the crop, volatility in price, lack of incentive to the farmers, as they do not see any future in producing the crop, as they are not provided with retirement plans. Lastly, the youth section is moving away to other career opportunities. To eradicate the problem of quality, Nespresso initiated a unique model on supply chain. The model stressed to associate with the non-governmental organization (NGO). The NGO has focused on sustainable farming practices that enabled to achieve the objective of quality coffee beans. The 'AAA' model initiated by Nespresso supplied high-quality seeds to the company. Along with this, it also enhanced the preserving process of the environment. The program also concentrates on farmer welfare and long-term relationship with the farmers (Alvarez et al., 2010). In addition to increment in the product quality, the program increased the income of the farmers and increased the yield rate along with sustainability of the yield. Colombian farms showed a growth of $22.6 \%$ in social conditions, $41 \%$ growth in the economic conditions of the farmers and 52\% increment in the environment conditions (Hock et al., 2016). On the other hand, the farms that did not follow the 'AAA' program remained stagnant in the same position (Matzler et al., 2013).

The third strategic benefit of the social innovation plan in food supply chain management is the motivation on improving the reputation of the brand and changing the taste and preference of the consumers proactively. Engaging the customers in a particular product increases the revenue of the company. The experience of C\&A, a leading retail fashion business, providing quality, affordable clothing to 100 million customers each year, can be used to explain this case. The company deals with (organic) cotton fibers in its product, and it makes use of cotton on almost $60 \%$ of its product. In the year 2004 , the company made a commitment to increasing the usage of sustainable cotton products. Simultaneously, the company concentrated on enhancing customer engagement along with brand equity. In the year 2009, the company made a partnership with Shell foundation and textile exchange (Seuring and Müller, 2008). These are social enterprises, which support the use of sustainable cotton in production. In the year 2014, the company claims to become the biggest retriever of sustainable cotton. Thus, the problem of sustainability was addressed with the implementation of social innovation plan. It aims to turn the production into $100 \%$ sustainable cotton by the end of the year 2020 
(World Economic Forum, 2018). Benefits through this innovation are the low cost of producing sustainable cotton, less dependency on the intermediaries and less vulnerability to the effects of climate change.

\section{Investment in talent}

Workplace diversity can create the opportunity for social innovation. The extensively diversified workforce that includes a greater pool of workers in an organization that introduces to new ideas and capabilities. The companies strive to address to these abilities by diversifying the workforce. According to the literature, $85 \%$ of the companies believe and agree to the fact that diversification in talent can lead to more innovative products (Mirvis et al., 2016). From the statistics, $48 \%$ of people believe the fact strongly. $32 \%$ of them partially agree to the fact, $11 \%$ of people partially disagree with the fact, $3 \%$ of them strongly disagree and $1 \%$ of them do not possess any idea regarding the relationship between innovation and diversified talent.

The experience of the Intercrop Group's investment in building talent to cater the employment problem in countries may serve as one of the best examples to validate the role of talent diversity. According to the Talent Shortage Survey conducted by the Manpower Group in the year 2015, Peru is a country that faces the problem of employment shortage (World Economic Forum, 2018). It is reported that $68 \%$ of the employers face difficulty to fill up the positions in the respective organization because of below standard education (Austin et al., 2006). Looking into this factor, intercrop invested in Innova schools. This investment provided better quality education to the children and to young youths at an affordable rate. The middle-income groups were able to send their children to schools because of low expenditure on education. Almost 19,000 beneficiaries were reported to have taken admissions in the Innova schools. Therefore, the problem of employment is also addressed by implementing social innovation strategies (Goldsmith, 2010).

\section{Leveraging the finances}

Social innovations can be significant to improve finances in the company. Companies like Telefonica and Morgan Stanley can serve as good examples to illustrate the growth of the social investment in food related areas. In case of Morgan Stanley, the target was to invest in start-ups leading to new entrepreneurial opportunities, including those entrepreneurs in food industries. Since the 1990's Morgan Stanley's Private Equity business has been concentrating on credit easing, i.e. to provide microfinance facilities to small and medium scale entrepreneurs (MacCallum, 2009). Previously, the source of credit was small informal channels and banks that charged a high rate of interest from the consumers. The role of Morgan Stanley is important for making the process sustainable investment easier (Froud et al., 2010). For example, Morgan Stanley's $\mathrm{K}$-food popularity project has launched a food revolution in Korea. Another example, an emergence of a Spanish telecommunication company named Telefonica made a partnership with the government of the United Kingdom to support the start-ups in growing their business. Ventures that are seeking the support of this organization are getting the benefit of solving the problem by referring to innovative digitization. The instruments that help to communicate with the ventures are radios and cell phones that help to make a peer-to-peer. With the help of this technology, approximately 43,000 farmers in parts of Latin America were benefitted. Farmers learned the innovative process to farm and increase productivity (Nicholls et al., 2015). In addition to basic financing helps, Telefonica also supports food industry entrepreneurs with competitive new digital services that enable the food businesses to offer better services to their customers.

\section{Conclusions}

This paper draw on a wider range of stakeholders beyond clients in food sector. The social innovation perspective demands more and more diverse set of stakeholders to be considered in the cocreation processes. This paper might stimulate further echoes and thoughts from academic and practical areas. Social innovation is defined as the creative development of the problem-solving strategy. It is needed to address various problems in living and ecology related affairs. As practical solutions, the mechanisms can be the employment of resources, sustainable development of resources, generation of finances and diversifying the talent pool. 
Explanations are provided using company example that influenced innovation in society in the food sector. The supply chain management issues in food industry are addressed with social innovation. Arrangement of raw materials helps the market to achieve price premiums and drive out the intermediaries that are affecting the small farmers. The investment of intercrop in Innova schools is driving away from the forces of poverty by empowering the children and youth through education. Participation in the workforce is increasing due to eligibility in the population. Financial investments are supported for start-ups by implementing innovative plans that affect society as a whole. Entrepreneurs, who are investing in new ventures, need financial help and financial advising, whether investing in a certain project will be viable or not. Social innovation on lending advice and funds to vulnerable organizations is the key to success. Therefore, it can be inferred that through social innovation, many vulnerabilities of the society such as unemployment, poverty, low living standards can be eradicated. Last but not least, social innovation helps in advancing the small-scale farmers and provides them with a livelihood.

\section{Conflicts of interest}

The authors declare no conflict of interest.

\section{Acknowledgements}

This research was supported by the National Key Research and Development Program of China (2017YFC1601700) and the Key Project of the National Natural Science Foundation of China 'Risk Identification and Early-warning of Food Safety in the Process of Production and Supply' (No.71633002).

\section{References}

Alvarez, G., C. Pilbeam and R. Wilding. 2010. Nestlé Nespresso AAA sustainable quality program: an investigation into the governance dynamics in a multi-stakeholder supply chain network. Supply Chain Management: an International Journal 15(2): 165-182.

Austin, J., H. Stevenson and J. Wei-Skillern. 2006. Social and commercial entrepreneurship: same, different, or both? Entrepreneurship Theory and Practice 30(1): 1-22.

Cajaiba-Santana, G. 2014. Social innovation: moving the field forward. A conceptual framework. Technological Forecasting and Social Change 82: 42-51.

Froud, J., S. Johal, J. Montgomerie and K. Williams. 2010. Escaping the tyranny of earned income? The failure of finance as social innovation. New Political Economy 15(1): 147-164.

Goldsmith, S. 2010. The power of social innovation: how civic entrepreneurs ignite community networks for good. John Wiley \& Sons, Hoboken, NJ, USA.

Hock, M., T. Clauss and E. Schulz. 2016. The impact of organizational culture on a firm's capability to innovate the business model. $R \& D$ Management 46(3): 433-450.

Huarng, K.H. and T. Hui-Kuang Yu. 2011. Entrepreneurship, process innovation and value creation by a non-profit SME. Management Decision 49(2): 284-296.

Lettice, F. and M. Parekh. 2010. The social innovation process: themes, challenges and implications for practice. International Journal of Technology Management 51(1): 139-158.

MacCallum, D. (ed.) 2009. Social innovation and territorial development. Ashgate Publishing, Ltd., Farnham, UK.

Matzler, K., F. Bailom, S. Friedrich von den Eichen and T. Kohler. 2013. Business model innovation: coffee triumphs for Nespresso. Journal of Business Strategy 34(2): 30-37.

Mirvis, P., M.E.B. Herrera, B. Googins and L. Albareda. 2016. Corporate social innovation: how firms learn to innovate for the greater good. Journal of Business Research 69(11): 5014-5021.

Mulgan, G. 2012. The theoretical foundations of social innovation. In: A. Nicholls and A. Murdock (eds.) Social innovation. Palgrave Macmillan, London, UK. 
Nicholls, A., J. Simon and M. Gabriel. 2015. Introduction: dimensions of social innovation. In: A. Nicholls, J. Simon, M. Gabriel and C. Whelan. (eds.) New frontiers in social innovation research. Palgrave Macmillan, London, UK, pp. 1-26.

Oke, A., D.I. Prajogo and J. Jayaram. 2013. Strengthening the innovation chain: the role of internal innovation climate and strategic relationships with supply chain partners. Journal of Supply Chain Management 49(4): 43-58.

Seuring, S. and M. Müller. 2008. From a literature review to a conceptual framework for sustainable supply chain management. Journal of Cleaner Production 16(15): 1699-1710.

Wook Kim, S. 2006. Effects of supply chain management practices, integration and competition capability on performance. Supply Chain Management: an International Journal 11(3): 241-248.

World Economic Forum. 2018. What are the business opportunities in pursuing social innovation? Available at: https://tinyurl.com/wlx3zw4 